\title{
Estimation of the Commercial Effect of a Colombia-Israel FTA: Trade Overview and Partial Equilibrium Analysis, 2004-2014*
}

\author{
Estimación del efecto comercial de un TLC entre Colombia e Israel: panorama y análisis de equilibrio parcial, \\ 2004-2014 \\ Estimativa do efeito comercial de um TLC entre a Colômbia e Israel: panorama e análise de equilíbrio parcial, \\ 2004-2014
}

\author{
Stella del Pilar Venegas Calle \\ Universidad Jorge Tadeo Lozano, Colombia \\ stellavenegas@gmail.com \\ ORCID: http://orcid.org/0000-0002-1662-6273 \\ Nicolás De la Peña Cárdenas \\ Universidad de la Salle, Colombia \\ ORCID: http://orcid.org/0000-0001-7223-9502
}

\author{
DOI: https://doi.org/10.11144/Javeriana.cao32-59.etcec \\ Redalyc: http://www.redalyc.org/articulo.oa? \\ id=cuadernoss 20561244001
}

Date received: 26 February 2018

Date accepted: 14 May 2019

\begin{abstract}
:
The study presents the quantitative effects of a total tariff tax exemption between Colombia and Israel. Tariff reduction simulations are carried out using a partial equilibrium model based on the SMART methodology. Before the model, some indicators are presented to show an overview of the degree of complementarity, similarity and comparative advantages revealed. The results show that the commercial effect is very low for both countries and that there are minimum potential risks. However, several opportunities of new exports for specific sectors are identified.
\end{abstract}

JEL Codes: F14, F15, F17

Keywords: International Trade Agreements, FTA Colombia-Israel, Trade Indicators, Agreement Assessment.

\section{Resumen:}

El estudio presenta los efectos cuantitativos de una exención fiscal arancelaria total entre Colombia e Israel. Las simulaciones de reducción de tarifas se realizan utilizando un modelo de equilibrio parcial basado en la metodología SMART. Antes del modelo, se presentan algunos indicadores para mostrar una visión general del grado de complementariedad, similitud y ventajas comparativas reveladas. Los resultados muestran que el efecto comercial es muy bajo para ambos países y que existen riesgos potenciales mínimos. Sin embargo, se identifican varias oportunidades de nuevas exportaciones para sectores específicos.

Códigos JEL: F14, F15, F17

Palabras clave: acuerdos comerciales internacionales, pronósticos, TLC Colombia-Israel, indicadores comerciales, evaluación de acuerdos.

\section{Resumo:}

Este artigo apresenta os efeitos quantitativos de uma isenção alfandegária total entre a Colômbia e Israel. As simulações de redução tarifária são feitas usando um modelo de equilíbrio parcial baseado na metodologia SMART. Antes do modelo alguns indicadores são apresentados para mostrar uma visão geral do grau de complementaridade, semelhança e vantagens comparativas reveladas. Os resultados mostram que o efeito comercial é muito baixo para ambos países e que existem riscos potenciais mínimos. No entanto, são identificadas várias oportunidades de novas exportações para setores específicos.

Códigos JEL: F14, F15, F17

Palavras-chave: acordos comerciais internacionais, previsões, TLC Colômbia-Israel, indicadores comerciais, avaliação de acordos.

\section{Author notes}




\section{Introduction}

Colombia and Israel have strengthened their economic ties during the last years. The total value of bilateral trade has quadrupled during the last decade (2004-2014), particularly in terms of Colombian exports. Nevertheless, the commercial volume is still minimum since the participation of the exports to Israel does not exceed 0.96 per cent in Colombia and the figure for the exports to Colombia is 0.48 per cent of the Israelite total. The relations between both countries have long had a political component. In recent times, both countries have turned to internationalization giving rise, in a rapid manner, to a series of commercial agreements that allow them exploiting their commercial capacities, strengthening the political relation, and making a contribution to the welfare of the economy.

Preferential Trade Agreements (PTAs) are a sensitive subject in Colombia. The means of communication repeatedly announce the economic disaster they give rise to, particularly in relation to agriculture and the vulnerable population. Conversely, it is commonly argued that they are an extraordinary tool for social development and economic growth. Nevertheless, evidence seems to demonstrate that they are neither one thing nor the other: their effects - both positive and negative- are minimal in terms of trade and the main benefit obtained from them is the dynamic effects of trade.

Israel has shown a growing commercial interest in Latin America and has been expanding commercial blocks rapidly; among them, the Pacific Alliance aimed at fulfilling its policy for expanding their industrial market (Shamah, 2015). In recent times negotiations have been started Panama (IMFA, March 3, 2015) and China (IMFA, March 30, 2015), aimed at reaching trade agreements. Colombia, for its part, seeks to open new markets in Asia and in the Middle East. That is why it has already signed -though not yet in placeagreements with Israel and South Korea; it is in talks with Japan and Turkey (MinCIT, March 15, 201 1; May 20, 2014). Both countries have agreements in common with the European Union, the United States, EFTA, México, Canada, and Mercosur.

This study intends to approach the ex ante assessment of the effects on international trade that the entering into force of the Free Trade Agreement -FTA- would have on international trade. The particular case tackled in this study intends to assess said impacts concerning the Colombia-Israel Agreement, mainly by calculating indicators and a model to estimate the creation, diversion, and welfare effects of trade, among others.

The document is structured in five sections. The first section has a brief literature review around the theories of economic integration and provides a theoretical framework based on which it is possible to understand the commercial possibilities and impacts of an agreement between Colombia and Israel. The second one contains the current economic and commercial outlook of the two economies in question through the use of descriptive statistics and the estimation of three important trade indicators that serve as a platform for the analysis of bilateral trade. The third section presents a partial equilibrium model showing the direct trade effects of a tariff reduction in relation to the creation and diversion of trade, welfare on consumers and producers, and changes in the government revenue. The fourth one summarizes the conclusions that could stem from the research, based on the findings of the work carried out.

\section{Literature Review}

In this section, in addition to presenting a review of some of the most recognized studies in the literature on FTA, ${ }^{1}$ it also produces a brief summary about the impacts that tariffs have on the welfare of consumers and producers from a theoretical point of view. Finally, the section presents a brief review of partial equilibrium models. 
An analysis of the potential effects that an FTA may represent for an economy may be addressed through the theory of integration or Customs Union. In that regard, the most well-known point of reference may date back to Viner's 1950 studies.

Jacob Viner studied integration trying to elucidate if Customs Unions led to freer trade or more protectionism upon identifying the advantages and disadvantages of economic integration from a static point of view. On that subject, Viner argued that there are both positive and negative effects in economic welfare when establishing the mentioned unions. The former, according to him, derived from the "creation of trade," while the latter are the result of "trade diversion". The creation of trade is the phenomenon through which national products are substituted for cheaper imports. Trade diversion occurs when cheap imports from outside the Union are substituted for more expensive imports from a member of the Union.

Five years later, the contributions made by J. E. Meade widened Viner's postulates. He stated that Viner's conclusions implied the application of a very strong assumption: inelastic demand and totally elastic offer. According to Meade, if the flexibility of these conditions is allowed -for example, using the now known Armington Elasticities-, it would give rise to what he called Trade Expansion.

Similarly, Lipsey's work questioned Viner's (1950) developments by arguing that the effects on welfare also depend on the impact on consumption. After Lipsey, other contributions to the theory of integration were made by Johnson (1958) or Corden (1972) whose works emphasize, in the case of the first author, in high efficacy and income level; and, in the case of the second author, in the importance of the profits and losses among the different economic agents (the government, producers and consumers).

Other advances of the static effects of economic integration derived from Viner's analysis, besides Made's and Lipsey's, were tackled by Spraos (1964) and Bhagwati (1971). On the other hand, dynamic effects are addressed by the works of Balassa (1961) and Cooper and Massell (1965).

Not only the static and dynamic effects gave rise to two research trends; yet, terms such as "first regionalism" and "second regionalism" were included by Jagdish Bhagwati (1992) into the theory in order to refer to the evolution of the static and dynamic integration theory, respectively. In the study on integration from a dynamic perspective, Balassa (1961) made a great contribution.

Besides those already mentioned, numerous studies have been carried out on the topic of integration. Among the many that exist there are studies that argue Viner's limitations concerning their application in developing countries. Examples of this are found in Meier in 1960, Abdel Jaber in 1971, and Andick and Dosser in 1971 documents. In relation to inclusion of employment, productivity and the effects of income, the researches of Demas (1965), Sakamoto (1969), and Abdel Jaber (1971) (Hosny, 2013, p. 140) have been published.

A positive point of view on economic integration for developing economies is represented by Bhambri (1962), Chou (1967), Linder and Wionczek (1966) and Axline (1977) concerning the benefits of trade diversion. About the political aspect, some authors addressing the topic are Krishna (1998), Lawrence (1997), Axline (1977), and Inotai (1991); and about the analysis of the relationship between free trade and labor, there are the documents of Wonnacott and Wonacott (1967).

More recently, several researches from authors that study the relationship between welfare and trade have been published, some of them are: Redding (2016) by extending a recent class of quantitative models of international trade to incorporate factor mobility within countries; McCalman (2018), whose research studies the relationship between income distribution and international integration, emphasizing in a firm's strategy space is expanded to include non-linear prices; Guei, Mugano \& Le Roux (2017) investigate if South Africa (SA) benefits from the EU-SA Free Trade Agreement and also the impacts this agreement has on South Africa's trade with Southern Africa and the rest of the world; and Święcki (2017) and Naito (2017). This latter paper explores how reallocations across heterogeneous firms induced by unilateral trade liberalization affect long run growth and welfare. 
Among the studies that use the SMART model are those of Jachia and Teljeur (1999), suggesting that in addition to trade creation, trade diversion also takes place and studying the impact of the proposed FTA between South Africa and the EU using a SMART model; the Mathur document (2014) using the SMART model and the WITS data to evaluate the benefits of trade from tariff liberalizations of the "Climate Smart Goods" in Ecuador; or Sulthon (2014), paper that attempts to evaluate the impact of Indonesia-China trade liberalisation in changing Indonesian trade and Indonesian society welfare.

It's important to mention that, currently, no scientific document explaining the commercial effects of an FTA between Colombia Israel has been found, so the present investigation constitutes a valuable contribution in the study of international trade praxis. $^{2}$

\section{Some theoretical elements on tariffs}

It is important to remember that, according to the theory, the fundamental effects of a tariff are related to: i) the increase in the price of the imports of the country adopted by it and, consequently, a decrease in the domestic consumption of this country (consumption effect and trade effect), and ii) the fact that the decrease of the imports promotes domestic production aimed at substituting imports (production effect). That is, tariffs are an indirect subsidy over domestic industries whose production competes against imported goods. In this sense, a tariff supposes an artificial change related to the allocation of the resources of the economy.

From the fiscal point of view, tax collection increases (income effect) and the redistribution of income is favored from the consumers towards the producers (redistribution effect) (Freire Rubio, et al., 2013, p.89). Finally, tariffs have an effect on welfare which differs if we take into account the type of analysis (general or partial) and the size of the economy under analysis (big or small).

As it is already known, a market is made up both by sellers and buyers. In a partial analysis, the changes in the offer or demand of any product do not affect the offer or demand of any other good. In addition, in the general case of a large country, imposing a tariff increases the price of the good or service in the domestic country and reduces the price in the foreign country. However, when the economy is small (it cannot influence prices in the world market), the tariff cannot decrease the price of the good it imports abroad. In this situation, the effect of the tariff is transferred entirely to the domestic prices thus causing the price of the imports to increase for the total amount of the tariff for producers and consumers in the small country, and the amount of imports will decrease in that economy; therefore, there is, indeed, a welfare loss. ${ }^{3}$

What is the effect on consumers and producers? Imposing the tariff, and its effect on the increase of the national price, forces the consumers to decrease the demand and the producers to increase the offer. The final effect is that the welfare of the consumers decreases and that of the producers increases. Nevertheless, there is a loss, indeed, in the welfare of this economy. By applying the already mentioned theory to the case of this article, it would be expected that the elimination of the tariff would lead to a decrease of the price of import in our country, which, in turn, would correspond to an increase in welfare.

\section{The Model: Description and data}

The most used methods for calculating the effects of trade liberalization are mainly General Equilibrium Models (GEMs) and Partial Equilibrium Models (PEMs.) Both the GEMs and the PEMs are incomplete: they have implicit shortcomings that prevent them from having full exactness (McKitrick, 1998; Contreras, Mendieta \& Huerta, 2012). Each one of these models has different strengths and weaknesses, so it is the duty of each author to determine the model to use according to the needs of the study. In general, the studies that 
relate several economies use GEMs and allow making interblock (Boyer \& Schushny, 2010) and intrablock calculations (Domingues, Haddad, \& Hewings, 2008).

In regards to the advantages, the main advantage of GEMs is the inclusion of different variables into the model, such as: exchange rate (Gracia \& Zuleta, 2009), multiple economies (Boyer \& Schushny, 2010), unemployment (Kitwiwattanachai, Doug \& Reed, 2010), according to Laird and Yeats (1990).

About the restrictions, one of the most notable of the GEMs is the limitation concerning the sectoral breakdown and the product level. Nevertheless, new and complex methodologies, as the one developed by Jean, Mulder, and Ramos (2014), achieve a 6-digit HS breakdown, but requires a lot of data (it includes 40 endogenous and 53 exogenous variables). These disadvantages may be avoided in Partial Equilibrium Models. Some specific analyses related to trade liberalization in Colombia using PEMs are limited in literature. One found is that of the authors Pereira, Gómez \& Herrera (2012).

The PEMs take into consideration the effects of a single policy in a particular economy. Thus, the analysis does not involve interactions among several markets or policies, which is the main difference concerning the GEMs. Regarding the advantages, the most important one has to do with the possibility of carrying out analyses at highly detailed levels (Francois \& Reinert, 1997). This becomes particularly relevant when analyzing the impacts of the commercial policy, specifically tariff reduction over a particular economy since it allows establishing those sectors, sub-sectors, and even groups of products that are affected by the change in the commercial policy. On the other hand, the main weakness of the PEMs lies in the sensitivity they evidence vis-à-vis the small number of variables they include; therefore, small differences in the data may lead to big changes in the results.

Given the above and based on the methodology of Laird and Yeats (1986), the SMART (Software for Market Analysis and Restrictions on Trade), is an ex ante partial equilibrium model (PEM) that measures the effects, based on a simulation of changes in trade policies, particularly in relation to tariff reduction. Therefore, it measures direct effects (static) of trade, which are trade creation, trade diversion (as explained above in the literature review) and government income effect. The trade data is taken from COMTRADE, the tariffs from WTO, and other information (as elasticities) from WITS.

A sectorial application of the SMART model, to assess the impact of multilateral policies, is found in Hernández (2007); Otheino and Shinyekwa (2011); and, Mugano, Le Roux and Brookes (2013). Regarding the Colombian case, the only studies that apply the SMART methodology are those carried out by Pereira, Gómez and Herrera (2012), and Gómez, Pereira and Gaitán (2013). Other calculations following the PEM -albeit only for specific sector- are found in Chique, Rosales and Samacá (2006), and Garay, Barberi and Cardona (2010).

\section{Economic and commercial outlook of Colombia and Israel}

What is the commercial situation of the two countries at present? A first approach that allows to delve into the possible impacts of an FTA between the two nations can be done by reviewing some macroeconomic statistics in each country and then making a description of their business relationships.

The economic environment of both economies, included in table 1, shows that Colombia has a higher gross domestic product-GDP-. However, the income difference is notable: the GDP per capita of Colombia corresponds to 40 per cent of Israel's GDP in 2014. The foregoing figures evidence the contrast in terms of the productivity per worker in each country and that of their productive structures. It is important to mention the noticeable difference of the expenditure of the government in research and development: Israel is one of the countries that spend the most in research \& development as a percentage of GDP around the world. This responds to their agricultural needs and to the development of its productive structure in terms on technology. 
TABLE 1

Basic economic characteristics of Colombia and Israel, 2009-2014

\begin{tabular}{|l|c|c|c|c|c|c|} 
Colombia & $\mathbf{2 0 0 9}$ & $\mathbf{2 0 1 0}$ & $\mathbf{2 0 1 1}$ & $\mathbf{2 0 1 2}$ & $\mathbf{2 0 1 3}$ & $\mathbf{2 0 1 4}$ \\
\hline $\begin{array}{l}\text { GDP, PPP } \\
\text { (2011 Constant SUSD million) }\end{array}$ & 481.410 & 500.530 & 533.513 & 555.088 & 582.489 & 609.006 \\
\hline $\begin{array}{l}\text { GDP per capita, PPA } \\
\text { (2011 Constant SUSD million) }\end{array}$ & 10.600 & 10.901 & 11.497 & 11.840 & 12.304 & 12.743 \\
\hline $\begin{array}{l}\text { Expenditure in R\&D } \\
\text { (per cent of GDP) }\end{array}$ & 0.18 & 0.18 & 0.18 & 0.22 & 0.22 & 0.23 \\
\hline Population & $45,416,276$ & $45,918,101$ & $46,406,446$ & $46,881,018$ & $47,342,363$ & $47,791,393$ \\
\hline Israel & $\mathbf{2 0 0 9}$ & $\mathbf{2 0 1 0}$ & $\mathbf{2 0 1 1}$ & $\mathbf{2 0 1 2}$ & $\mathbf{2 0 1 3}$ & $\mathbf{2 0 1 4}$ \\
\hline $\begin{array}{l}\text { GDP, PPP } \\
\text { (2011 Constant SUSD million) }\end{array}$ & 212.730 & 224.963 & 234.391 & 241.413 & 249.255 & 256.151 \\
\hline $\begin{array}{l}\text { PIB per capita, PPA } \\
\text { (2011 Constant SUSD million) }\end{array}$ & 28.621 & 29.653 & 30.574 & 30.879 & 31.294 & 31.485 \\
\hline $\begin{array}{l}\text { Expenditure in R\&D } \\
\text { (per cent of GDP) }\end{array}$ & 4.17 & 3,97 & 3.97 & 4.10 & 4.25 & 4.21 \\
\hline Population & $7,485,600$ & $7,623,600$ & $7,765,800$ & $7,910,500$ & $8,059,500$ & $8,215,300$ \\
\hline
\end{tabular}

Source: authors compilation based on data from the World Bank and the International Monetary Fund.

The commercial relationship between Colombia and Israel, albeit small in terms of values traded, has evidenced noticeable growth. Exports from Colombia to Israel have increased from US \$90 million in 2003 to US $\$ 526$ million in 2014 , meaning a 490 per cent growth. Imports have gone from US $\$ 72$ million to US $\$ 328$ million during the same period analyzed, meaning a 355 per cent growth. Therefore, Colombia-Israel trade keeps a positive trade balance through the window of the study, except for 2010. (Graph 1).

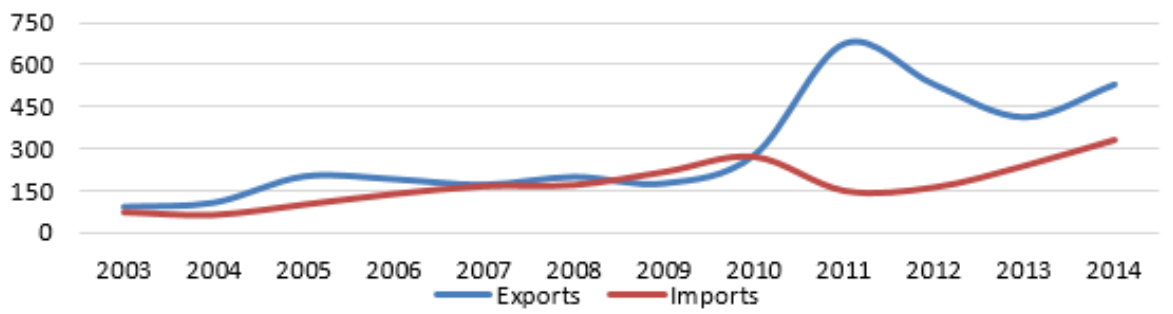

GRAPH 1

International Trade: Colombia with Israel (\$USD Million)

Source: Authors compilation based on data from International Trade Center.

In 2014, the trade surplus reached US $\$ 173$ million and the trade between Colombia and Israel reached the highest value recorded in history: US $\$ 854.5$ million. Concerning the average annual growth of Colombian exports, during the period from 2010 to 2014, the country records a 32 per cent rate by concentrating its shipments, almost exclusively, on mineral fuels and oils: the shipments from that sector for 2014 represent 94 per cent of the trade with Israel. See table 2.

TABLE 2

Ten main products exported from Colombia to Israel, 2014

\begin{tabular}{|l|r|r|}
\hline \multicolumn{1}{|c|}{ Description of the Product } & \multicolumn{1}{|c|}{ Value in S USD } & $\begin{array}{c}\text { Per cent participation } \\
\text { of the total (\%) }\end{array}$ \\
\hline \begin{tabular}{l|r|} 
Mineral fuels and oils, and products from their \\
distillation
\end{tabular} & $494,988,000$ & 94.02 \\
\hline Coffee, tea, mate, and spices & $15,019,000$ & 2.85 \\
\hline $\begin{array}{l}\text { Fine or cultured pearls, precious stones, semi- } \\
\text { precious stones and similar stones }\end{array}$ & $3,585,000$ & 0.68 \\
\hline Arms and ammunitions; their parts and accessories & $2,536,000$ & 0.48 \\
\hline $\begin{array}{l}\text { Optics, photography and cinematography } \\
\text { instruments and devices }\end{array}$ & $2,045,000$ & 0.39 \\
\hline Wood, charcoal, and wood manufactured products & $1,744,000$ & 0.33 \\
\hline Sugars and candies & $1,548,000$ & 0.29 \\
\hline Plastic materials and plastic manufactured products & $1,182,000$ & 0.22 \\
\hline $\begin{array}{l}\text { Nuclear machines, reactors; boilers, mechanical } \\
\text { devices and artifacts }\end{array}$ & 964,000 & 0.18 \\
\hline $\begin{array}{l}\text { Electrical machines, devices and materials, and } \\
\text { their parts; recording devices }\end{array}$ & 746,000 & 0.14 \\
\hline Total - main 10 products exported & $524,357,000$ & 99.60 \\
\hline Total products exported & $\mathbf{5 2 6 , 4 4 7 , 0 0 0}$ & $\mathbf{1 0 0 . 0 0}$ \\
\hline
\end{tabular}

Source: authors compilation based on data from International Trade Center.

Historically speaking, the political relationship that exists between Colombia and Israel has been highly tied to security and defense (Ramírez, 1989) and it keeps strengthening (Beris, 2008; Padilla, 2009); this is 
reflected on arms trade. Besides, Israel is for Colombia the main export destination and the third one for military equipment after the United States and South Korea.

It is important to mention that, among the ten main products exported from Colombia to Israel, five of them belong to the primary sector: arms; optics, photography and cinematography devices; plastic materials; mechanical machines and artifacts; and, electrical and recording devices. The foregoing shows that, despite the concentration in values exported, in relation to mineral fuels and oils, there is moderate diversity in the Colombian export sector.

Concerning Colombian imports from Israel, they have evidenced a 12 per cent average annual growth during the last five years between 2010 and 2014. During the last year, the goods received are concentrated in air navigation devices and electrical machines, which represent up to 60.3 per cent of the purchases made by Colombia to Israel, see table 3 .

TABLE 3

The ten main products imported by Colombia from Israel 2014

\begin{tabular}{|l|r|c|}
\hline \multicolumn{1}{|c|}{ Description of the product } & Value in \$ USD & $\begin{array}{c}\text { Per cent participation } \\
\text { of the total (\%) }\end{array}$ \\
\hline Air or space navigation & $124,327,000$ & 37.88 \\
\hline $\begin{array}{l}\text { Electrical machines, devices and material, their } \\
\text { parts; recording devices }\end{array}$ & $73,519,000$ & 22.40 \\
\hline $\begin{array}{l}\text { Optics, photography and cinematography } \\
\text { instruments and devices }\end{array}$ & $36,900,000$ & 11.24 \\
\hline $\begin{array}{l}\text { Nuclear machines, reactors; boilers, devices and } \\
\text { mechanical artifacts }\end{array}$ & $28,818,000$ & 8.78 \\
\hline Arms and ammunitions, their parts and accessories & $14,300,000$ & 4.36 \\
\hline Plastic materials and plastic manufactured products & $8,234,000$ & 2.51 \\
\hline Synthetic or artificial filaments & $6,077,000$ & 1.85 \\
\hline Padding, felt, unwoven fabrics; yarns & $5,067,000$ & 1.54 \\
\hline Diverse chemical products & $4,953,000$ & 1.51 \\
\hline Organic chemical products & $2,578,000$ & 0.79 \\
\hline Total main 10 products imported & $304,773,000$ & 92.86 \\
\hline Total products imported & $328,207,000$ & 100.00 \\
\hline
\end{tabular}

Source: authors compilation based on data from International Trade Center.

It is noted that the imports of the ten products correspond, entirely, to manufactured products, including: navigation technology; electrical machinery and materials; optics, photography and cinematography instruments; and, nuclear machines and reactors. They represent an important component which, in the aggregate, is 80.3 per cent within the ranking of the ten main products. Then, it is deduced that Israel's exports to Colombia evidence greater diversification. While in relation to the exports one product covers 94 per cent of them, more than ten products have to be accounted in order to reach an equivalent percentage.

On the other hand, analyzing trade participation (the share of trade with the partner against the total trade of the country) allows measuring the relative weight of trade in both countries and understanding, in a general manner, how important it is and how intense a commercial agreement will be. A higher commercial participation means that the changes in the patterns of bilateral agreements impact the implied economies more deeply. On average, during the years studied (2003-2014), the Israelite participation in Colombian trade was 0.58 per cent $(0.24$ in $2003 ; 0.60$ in 2014), and the Colombian participation in Israelite trade was 0.40 per cent $(0.60$ in 2003; 0.72 in 2014). It is notable that Israel's participation in Colombian trade has evidenced a growing trend, nearly tripled if compared to the 2004 and 2014 levels. What are the implications of this? Mainly, that the impacts of a trade agreement will not be deep given the minimum trade levels and that Israel, unlike Colombia, has been increasing its trade participation levels, maybe due to the diversification of exports.

The analysis of the bilateral trade balance leads us to some hypotheses. First, the Colombian products exported to Israel complement the production of the Israel; second, the imports from Israel do not entail a threat against Colombia's national production; third, there are comparative advantages for each country, given the specialization and the differentiation the markets evidence in relation to the type of product.

A statistical analysis was carried out of the international trade data of Colombia and Israel with the purpose of testing the hypotheses expressed. The trade complementarity index was calculated in order to test the first 
hypothesis; the similarity index was used for the second hypothesis; the revealed comparative advantage index was used for the third hypothesis.

\section{Complementarity index}

The Complementarity Index (CI) determines the potential of the commercial exchange between two economies. It allows calculating the coincidence of the exports of one of them and the imports of the other. In other words, it shows if the goods exported by a country are demanded by its commercial partner. According to the methodology described by Michaely (1996), the CI is defined as follows:

$$
C I_{i j}^{k}=100 *\left[1-\sum_{k=1}^{n} \frac{\left|M_{i}^{k}-X_{j}^{k}\right|}{2}\right]
$$

Where: $M_{i}^{k}$ is the participation of good $k$ in the imports of country $i ; x_{j}^{k}$ is the participation of good $k$ in the exports of country $j$; and $n$ is the number of goods.

\section{Similarity index}

The level of competition in the international trade between both countries can be calculated by using the Similarity Index (SI) since it allows measuring the homogeneity of the exports of two economies and establish if the exports of the partner country pose a risk to the national production.

The possible results of the indicator range between zero and one. If the economies have absolutely heterogeneous structures, the result will be $S I=0$ and, therefore, competition will be nonexistent. In contrast, when the economies have export structures that are completely homogenous, the result obtained shall be SI $=1$ and, therefore, competition will be strong. The historical analysis of the SI allows establishing the convergence or divergence of the export structures of both countries. The following is the mathematical formula:

$$
\mathrm{SI}=\sum_{k=1}^{n} \operatorname{Min}\left[\frac{X_{i}^{k}}{X T_{i}}, \frac{X_{j}^{k}}{X T_{j}}\right]
$$

Where: $x_{i}^{k}$ is the export of good $k$ of country $i ; x_{j}^{k}$ is the export of good $k$ of country $j ; x T_{i}$ is the total export of country $i ; x T_{j}$ is the total export of country $j$; and $n$ is the number of goods.

The result of the CI, shown in Table 4, evidences that both countries have similar and high complementarity; a decreasing trend is noted during the least years in Israel. The 2003-2014 complementarity average of Colombia with Israel is 48 , and 47 for Israel with Colombia. Both economies exceed the CI $=40$ threshold; therefore, it is possible to state that they are highly complementary (Davis, Handslow \& Sanders, 2009). In brief, Colombia and Israel demand, on average, 48 per cent of the products each one offers in its total exports. Then, it is worth remembering that bilateral exports, particularly Colombian exports, are highly concentrated on the ten main products (see table 2); therefore, the CI acquires special relevance when it demonstrates that there is a potential market for both economies that a Trade Agreement could boost. The results show that the SI between Colombia and Israel is low and evidences a decreasing trend, as seen in 
Table 4. The historical verification allows inferring that the SI has not been high since 2003, and that there has been divergence in the export structure of both countries which has become more noticeable in time. In other words, Colombia and Israel export more different products every time. This shows that the negative impact on the national productive sector will be very low since the export structures of Colombia and Israel are heterogeneous at a level higher than 80 per cent in 2014. Thus, a trade agreement between both countries poses not only the absence of risk for national production but also interesting trade opportunities.

TABLE 4

Complementarity index and Similarity index for Colombia and Israel

\begin{tabular}{|l|c|c|c|c|c|c|c|c|c|c|c|c|}
\cline { 2 - 12 } \multicolumn{1}{c|}{} & 2003 & 2004 & 2005 & 2006 & 2007 & 2008 & 2009 & 2010 & 2011 & 2012 & 2013 & 2014 \\
\hline $\begin{array}{l}\text { Complementarity Index } \\
\text { for Colombia }\end{array}$ & 50 & 48 & 50 & 49 & 49 & 49 & 49 & 48 & 45 & 48 & 47 & 47 \\
\hline $\begin{array}{l}\text { Complementarity Index } \\
\text { for Israel }\end{array}$ & 44 & 44 & 48 & 50 & 51 & 53 & 51 & 47 & 44 & 47 & 45 & 41 \\
\hline $\begin{array}{l}\text { Similarity Index } \\
\text { Colombia-Israel }\end{array}$ & 0.27 & 0.25 & 0.24 & 0.24 & 0.24 & 0.24 & 0.26 & 0.24 & 0.21 & 0.22 & 0.20 & 0.19 \\
\hline
\end{tabular}

Source: authors compilation based on data from International Trade Center.

\section{Normalized revealed comparative advantage index}

International trade theory affirms that economic benefits from trade come from specialization in efficient sectors, which are determined by a country's comparative advantage (Plummer, Cheong \& Hamanaka, 2010). These sectors are the ones that have to generate higher economic benefits and those in which industrial promotion and export policies should be more emphasized. To that end, the measure of comparative advantages through an index is useful.

But those indexes are much contested in economic literature (Danna-Buitrago, 2008). Since the classical formulation of Balassa (1965), there have been numerous studies showing limitations and problems, specially related with magnitudes, biases and comparability (Yu, Cai \& Leung, 2009). Balassa's index (1960) identifies the existence or not of advantage, nor its magnitude, what limits its capacity to determine relevance of products. ${ }^{4}$ In addition, it has a bias consisting of indicating stronger comparative advantages to the "smaller" country and to "small" commodities (Yeats, 1985). Other studies have tried to correct some problems related to comparability, but are either comparable across commodities but not across countries, as the proposed by Hoen \& Oosterhaveb (2006), or comparable between countries but not between commodities, as Proudman and Redding (1998).

In that sense, the Normalized Revealed Comparative Advantage Index (NRCAI) proposed by Yu et al. (2009) has the advantage of being comparable between countries or commodities, corrects the "small bias", and its results are indicative of the strength of the advantage, as an example: a result of 0.5 shows that the advantage is five times stronger than a result of 0.1 .

The results of the index are read as follows: NRCAI $>0=$ advantage; NRCAI $<0$ disadvantage. The values are between -1 and $1 .^{5}$

The NRCAI is defined as follows:

$$
N R C A I_{i j}^{k}=\frac{X_{i j}^{k}}{X T_{i}}-\left(\frac{X T_{i j}}{X T_{i}} * \frac{X T_{i}^{k}}{X T_{i}}\right)
$$

Where: $x_{i j}^{k}$ is the export of good $k$ by country $i$ to country $j ; x T_{i j}$ is the total export from country $i$ to country $j$; $x T_{i}^{k}$ is the total export of good $k$ from country $i$; and, $x T_{i}$ is the total export of country $i$. The calculation is made for 5554 products (HS-6 classification) both from Colombia's and Israel's point of view, thus establishing each one's comparative advantages. The result presents the average index for the 2012-2014, for bilateral trade between Colombia and Israel. 
The results of the NRCAI are dissimilar between both economies. Colombia has a favorable index in 17 products, which means that these products have comparative advantage vis-à-vis Israel and therefore, have a strong export potential and should be promoted. It is important to highlight that among the favorable products there are products with technological features such as parts of arms, parts of turbojets and integrated circuits. Likewise, coal is among the favorable products. It is also noted that Israel has more products (113) with a positive NRCAI which include electronic devices, weapons, medical and aeronautical machines, others related with paper industry, and some textiles. Very few agricultural products are identified, mainly vegetable seeds, suggesting that there will be little risk to national farming industry in Colombia. Tables that specify the products with advantages for both countries are shown in annex.

Does this mean that the Trade Agreement will be very favorable for Israel and moderately beneficial for Colombia? The fact that Colombia has few sectors with an advantage shows that its productive structure is fairly developed, but the Agreement will allow strengthening sectors that already have an advantage; in addition, as noted in table 4, export structures are different. This is the reason why the exports from Israel are not a threat against the Colombian economy. Nonetheless, the foregoing does not mean that there will not be any sector affected. An example of this is flower-growing products.

\section{The model}

The notation of the variables describing the model is as follows:

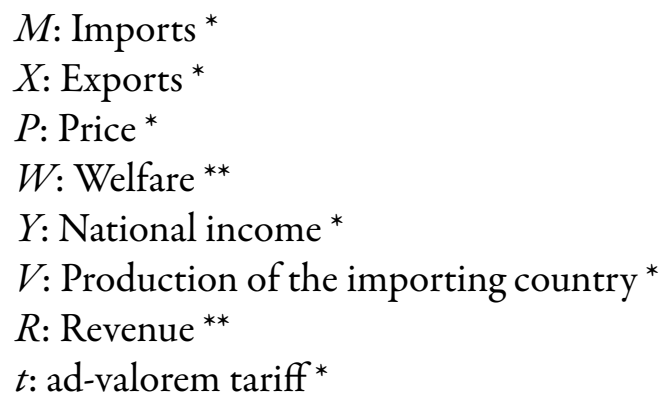

Em: Elasticity of the import demand with respect to domestic price *

$E x$ : Elasticity of the export supply with respect to export price *

Es: Substitution elasticity with respect to relative prices of the same products from different offer sources (countries)*

$C C:$ Trade creation ${ }^{* *}$

$D C$ : trade diversion **

$i$ : Specific product sub-index

$j:$ Sub-index for data of the importer or domestic market

$k$ : Sub-index for data of the exporter or foreign market

$\Delta$ : Variation

Note: ${ }^{*}$ Corresponds to an exogenous variable and ${ }^{* *}$ to an endogenous one. This classification is made taking into account the final equations with which the model estimates are made.

The basic model. ${ }^{6}$ The import demand function $(M)$ of country $j$ of good $i$ from country $k$ is expressed as follows:

$$
M_{i j k}=F\left(Y_{j}, P_{i j}, P_{i k}\right)
$$


The export supply function $(X)$ of country $k$ of good $i$ is expressed as follows:

$$
X_{i j k}=F\left(P_{i k j}\right)
$$

Equations (4) and (5) are related by the following identity:

$$
M_{i j k}=X_{i k j}
$$

Assuming that under a free-trade situation the domestic price of good $i$ in import market $j$ shall be equivalent to the export price of country $k$ plus insurance and freight (CIF) costs; therefore, this price shall change at an amount equivalent to ad-valorem tariff. This is shown as:

$$
P_{i j k}=P_{i k j}\left(1+t_{i j k}\right)
$$

Export revenues $R$ of country $k$ are:

$$
R_{i j k}=X_{i k j}\left(P_{i k j}\right)
$$

Trade Creation. Taking into account the equations of the basic model, it is possible to obtain the trade creation $(T C)$ formula. In the first place, the total differential of the domestic price is derived with respect to the tariffs and the foreign (world) price:

$$
\Delta P_{i j k}=P_{i k j} * \Delta t_{i j k}+\left(1+t_{i j k}\right) * \Delta P_{i k j}
$$

The following is the equation of the elasticity of the import demand $(E m)$ in relation to the domestic price:

$$
E m=\frac{\frac{\Delta M_{i j k}}{M_{i j k}}}{\left(\frac{\Delta t_{i j k}}{\left(1+t_{i j k}\right)+\frac{\Delta P_{i j k}}{P_{i k j}}}\right)}
$$

The following is the equation for the elasticity of the export supply $(E x)$ in relation to the domestic price:

$$
E x=\frac{\frac{\Delta X_{i k j}}{X_{i k j}}}{/ \frac{\Delta p_{i k j}}{P_{i k j}}}
$$


From equation (6), and taking into account equation (11) which is export elasticity and (10) which is import elasticity, we get partial equilibrium:

$$
\frac{\Delta M_{i j k}}{M_{i j k}}=\frac{\Delta X_{i k j}}{X_{i k j}}
$$

The effect of $T C$ corresponds to the increase of the demand in country $j$ for good $i$ offered by country $k$ as a result of the lower price associated to the tariff reduction:

$$
T C_{i j k}=\frac{M_{i j k * E m * \Delta t_{i j k}}}{\left(\left(1+t_{i j k}\right)(1(E m / E x))\right)}
$$

Taking into account that the assumption of the model is that the elasticity of the exports $(E x)$ is infinite, then the denominator in the previous equation may be ignored. The result is:

$$
T C_{i j k}=M_{i j k} * E m * \Delta t_{i j k}
$$

Trade Diversion. The trade diversion effect $(T D)$ corresponds to the substitutions of goods from a foreign supplier to another one which benefits from the tariff reduction. As the model uses, by default, a 1.5 value for the elasticity of substitution $(E s)$, then the relevant equation is:

$$
E s=\frac{\Delta\left(\sum M_{i j k} / \sum M_{i j K}\right) /\left(\sum M_{i j k} / \sum M_{i j K}\right)}{\Delta\left(P_{i j k} / P_{i j K}\right) /\left(P_{i j k} / P_{i j K}\right)}
$$

Where, $k$ represents the imports of a country or group of foreign countries; and, $K$ is the import of another country or groups of foreign countries. The summation is just among the countries or group of countries $k$ or $K$ but not among products $i$ or imports $j$.

Based on the previous equation, it is possible to express the percentage of change in the relative quotas of alternative suppliers in relation to the elasticity of substitution. Thus, the following equation may be obtained for calculating the $T D$ :

$$
T D_{i j k}=\frac{M_{i j k}}{\sum M_{i j k}} * \frac{\sum M_{i j k} \sum \sum M_{i j K} * E s * \frac{\Delta\left(P_{i j k} / P_{i j K}\right)}{P_{i j k} / P_{i j K}}}{\sum M_{i j k}+\sum M_{i j K}+\sum M_{i j k} * \frac{\Delta\left(P_{i j k} / P_{i j K}\right)}{P_{i j k} / P_{i j K}}}
$$


Total Trade Effect. The result of the total trade effect $(T E)$ is obtained from the summation of $T C$ and $T D$ effects. Likewise, they may be added among products or groups of products, as for suppliers and groups of suppliers.

$$
T E=T C+T D
$$

Revenue Effect. Since in the model used the income of the exporter will not be affected by the price because the elasticity of the export supply $(E x)$ is infinite in the model, then the earnings will be determined only by the export volume. Thus, the percentage of change in the income will be in proportion to the percentage of change in the exports without taking into consideration the percentage of the increase of the prices. The equation is as follows:

$$
\frac{\Delta R_{i j k}}{R_{i j k}}=E m *\left(\frac{\Delta t_{i j k}}{\left(1+t_{i j k}\right)}\right) *\left(\frac{(1+E x)}{(E x-E m)}\right)
$$

Welfare Effect. The Welfare Effect $(W)$ arises from the benefits of the consumer of the importing country generated by the decrease in the prices after the reduction of the tariffs. The general welfare of the economy increases when the income generated by the tariff is transferred from the government to the consumer; in addition, there is an increase in the level of imports. Therefore, the net effect of welfare in the economy is calculated as the average between the variation of the values of the imports and the variation of the ad-valorem tariff. The increase in welfare may be described as the increase in the consumer surplus. ${ }^{7}$ The equation is as follows:

$$
W_{i j k}=0,5\left(\Delta t_{i j k} * \Delta M_{i j k}\right)
$$

The model takes into consideration the following assumptions: 1) the base year from which the tariff reduction simulation was carried out is 2014 . The foregoing, because the agreement has not entered into force yet and reductions have not taken place. That one is the most recent year to date. 2) The tariff reduction was assumed at 100 per cent for all the products on one single date. This means that no analysis was carried out along with a tax exemption schedule. The limitations of this assumption are that, once the FTA is in place, the tax exemption level would be fully reached after 16 years. 3) The products included in the simulation correspond to the entire tariff universe broken down into six digits (HS-6). 4) The countries included in the simulation correspond to the 200 stored in the WITS database (based on COMTRADE). 5) The export elasticities are assumed as infinitely elastic (99) which entails an offer that is also infinite. 6) The import substitution (with a 1.5 value) assumes the imperfect substitution between domestic and foreign goods. 7) The import elasticities varies for each product and applies Armington assumption -according to the information of International Trade Center available in WITS. 


\section{Results of the partial equilibrium simulation}

\section{Simulation for Colombia}

The results of the trade effect for Colombia included in Table 5 show that the total earnings derived from the tariff tax exemption are US $\$ 4.78$ million. It is evident that the country that benefits the most from the trade agreement is Israel since its trade effect is US \$10.81 million: just US \$4.78 million derived from trade creation. In other words, it is the value that the trade agreement would generate after displacing inefficient national producers in favor of more efficient foreign producers. On the other hand, of the total trade effect, US $\$ 6.04$ million are caused by trade diversion; that is, inefficient producers from Israel displace more efficient producers of other commercial partners of Colombia, mainly the United States, China and Mexico. What are the implications for Colombia?

TABLE 5

Trade Creation, Diversion and Effect on Commercial Partners of Colombia (USD\$ Million)

\begin{tabular}{|l|c|c|c|}
\hline \multicolumn{1}{|c|}{ Commercial Partner } & Trade Effect & Trade Creation & Trade Diversion \\
\hline Israel & 10.81 & 4.78 & 6.04 \\
\hline United States & -1.63 & 0.00 & -1.63 \\
\hline China & -1.17 & 0.00 & -1.17 \\
\hline Mexico & -0.63 & 0.00 & -0.63 \\
\hline Brazil & -0.32 & 0.00 & -0.32 \\
\hline Taiwan & -0.26 & 0.00 & -0.26 \\
\hline Peru & -0.25 & 0.00 & -0.25 \\
\hline Italy & -0.21 & 0.00 & -0.21 \\
\hline Germany & -0.17 & 0.00 & -0.17 \\
\hline Chile & -0.14 & 0.00 & -0.14 \\
\hline Rest of the World & -1.25 & 0.00 & -1.25 \\
\hline Total & 4.78 & 4.78 & 0.00 \\
\hline
\end{tabular}

Source: authors compilation based on SMART.

Some effects for our country may be seen in Table 6 . This table presents the products that generate a trade effect higher than US $\$ 50,000$. It is possible to state that these would be the groups that would obtain the greater benefit from the trade agreement. The welfare effect, which is equivalent to the consumer surplus, is US $\$ 0.31$ million. The fiscal losses derived from the tariffs, equivalent to the income effect, reach US \$5.38 million. The following are the groups of products that generate the trade effect the most: yarns made of nylon synthetic filaments; baby diapers; and, plastics and their products made of ethylene polymer. It is important to emphasize that there are two groups related to the military industry: revolvers and parts of long arms. Of the 26 groups shown in table 6 , only one (orchids) corresponds to primary commodities.

TABLE 6

Trade Effect, Welfare Effect, and Income Effect in Colombia (USD\$ Million)

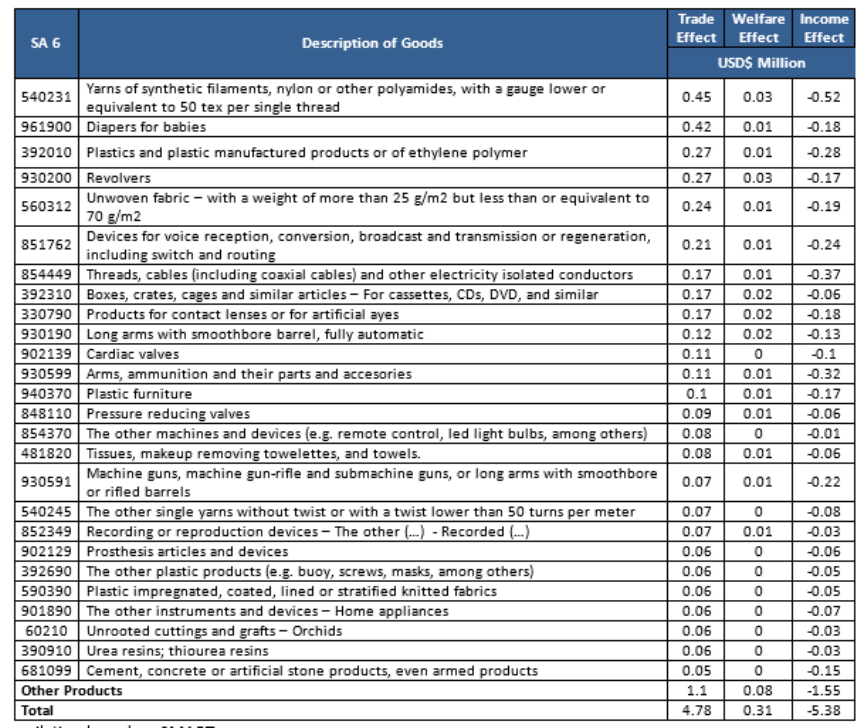

Source: authors compilation based on SMART. 


\section{Simulation for Israel}

The results of the trade effect for Israel included in Table 7 show that the total earning generated by the tariff exemption are US $\$ 230.23$ million. The country that benefits the most is Colombia since its trade effect reaches US $\$ 529.32$ million; of them, US $\$ 286.64$ correspond to trade diversion which is the value generated because of displacing producers from other countries (Israel's partners) that are more efficient than Colombia but do not benefit from the tariff reduction. The remainder of the value of the trade effect is caused by trade creation which is the value generated when displacing Israelite producers that are less efficient than the Colombian exporters. Those countries that are affected the most by trade diversion are, mainly, the United Kingdom, China, and Turkey.

TABLE 7

Creation, diversion and trade effect in Israel's commercial partners (USD\$ Million)

\begin{tabular}{|l|c|c|c|}
\hline \multicolumn{1}{|c|}{ Commercial Partner } & Trade Effect & Trade Creation & Trade Diversion \\
\hline Colombia & 529.32 & 230.23 & 286.64 \\
\hline United States & -46.92 & 0.00 & -46.92 \\
\hline United Kingdom & -44.56 & 0.00 & -44.56 \\
\hline China & -38.11 & 0.00 & -38.11 \\
\hline Turkey & -33.27 & 0.00 & -33.27 \\
\hline Italy & -14.59 & 0.00 & -14.59 \\
\hline Sweden & -10.94 & 0.00 & -10.94 \\
\hline France & -6.13 & 0.00 & -6.13 \\
\hline Belgium & -5.94 & 0.00 & -5.94 \\
\hline Hong Kong & -5.41 & 0.00 & -5.41 \\
\hline Rest of the World & -23.27 & 0.00 & -23.27 \\
\hline Total & 300.19 & 230.23 & 57.50 \\
\hline
\end{tabular}

Source: authors compilation based on SMART.

What are the implications of this situation for Colombia? Table 8 shows the products that could profit more from the advantages generated by the trade agreement with Israel. Table 8 presents the products that generate said trade effect higher than US $\$ 1$ million. It is possible to state that these would be the groups that would obtain the greatest benefit from the trade agreement. The welfare effect, which is equivalent to the consumer surplus, is US $\$ 4.13$ million. The fiscal losses related to the tariffs, equivalent to the income effect, reach US $\$ 222.8$ million. The groups of products that generate more trade effect are: tissues, makeup removing towelettes and towels - they generate half the trade effect-; swimsuits for women and girls; and, demijohns, bottles, jars and similar products.

TABLE 8

Trade effect, welfare effect, and income effect in Israel (USD\$ Millions)

\begin{tabular}{|c|c|c|c|c|}
\hline \multirow[t]{2}{*}{ SA 6} & \multirow{2}{*}{ Description of Goods } & $\begin{array}{l}\text { Trade } \\
\text { Effect }\end{array}$ & $\begin{array}{c}\text { Welfare } \\
\text { Effect }\end{array}$ & $\begin{array}{c}\text { Income } \\
\text { Effect }\end{array}$ \\
\hline & & \multicolumn{3}{|c|}{ USDS Millions } \\
\hline 481820 & Tissues, makeup removing towelettes, and towels & 115.11 & 1.12 & -118.93 \\
\hline 611241 & Bathing suits for women or girls - Synthetic fibers & 26.84 & 1.2 & -1.53 \\
\hline 392330 & Demijohns, bottles, jars and similar products & 20.88 & 0 & -19.53 \\
\hline 392410 & \begin{tabular}{|l|} 
Dinnervare and other articles for table or kitchen service \\
\end{tabular} & 18.31 & 0 & -21.76 \\
\hline 950300 & Tricycles, scooters, pedal cars and similar toys; dolls; the other toys; puzzles & 10.28 & 1.81 & -16.23 \\
\hline 170490 & Chocolates and candies - The other (...) & 6.33 & 0 & -7.66 \\
\hline 481890 & Paper and cardboard; cellulose paste, paper or cardboard products - The other (...) & 5.59 & 0 & -2.82 \\
\hline 210690 & Sundry food products & 4.38 & 0 & -4.8 \\
\hline 30111 & Ornamental fish - fresh water & 3.8 & 0 & -4.48 \\
\hline 854370 & The other machines and devices (e.g. remote controls, led light bulbs, among others) & 3.02 & 0 & -1.85 \\
\hline 961900 & \begin{tabular}{|l|} 
Diapers for babies \\
\end{tabular} & 2.99 & 0 & -2.31 \\
\hline 590390 & \begin{tabular}{|l|l} 
Plastic impregnated, coated, lined or stratified knitted fabrics - The other (...) \\
\end{tabular} & 2.01 & 0 & -1.9 \\
\hline 961590 & Combs, barrettes and other hair products & 1.91 & 0 & -3.13 \\
\hline 700721 & $\begin{array}{l}\text { Glass and its products - that allow their use in automobiles, aircrafts, ships or other } \\
\text { vehicles }\end{array}$ & 1.56 & 0 & -1.18 \\
\hline 380899 & Insecticides, herbicides & 1.36 & 0 & 0 \\
\hline 350610 & Products of any type used as glue or adhesives to be retailed & 1.35 & 0 & -1.61 \\
\hline 481910 & Paper or corrugated cardboard boxes & 1.23 & 0 & 0 \\
\hline 170410 & Gum and other chewing gums, even sugar-coated & 1.17 & 0 & -1.37 \\
\hline 700729 & \begin{tabular}{|l|l} 
Plied glass \\
\end{tabular} & 1.09 & 0 & 0 \\
\hline 180690 & Chocolate and other food products that have cocoa - Sugar-free - The other (...) & 1.03 & 0 & -1.35 \\
\hline \multicolumn{2}{|r|}{ Other products } & 0.01 & 0 & -10.41 \\
\hline \multicolumn{2}{|l|}{ Total } & 230.24 & 4.13 & -222.84 \\
\hline
\end{tabular}

Source: authors compilation based on SMART

It is important to highlight that, from the 20 groups mentioned in Table 8 , only one corresponds to primary goods: fresh water ornamental fish. On the other hand, the Colombian products that would have more export potential to Israel are manufactured products. 


\section{Conclusions}

Based on the verification of the theory through the use of indicators and of the model developed in this study, and the review of the agreement in question, there are several conclusions that could be drawn. In the first place, the Colombia-Israel FTA is identified as a third-generation agreement due to the fact that it transgresses the mere tariff reduction by including other provisions related to customs cooperation, sanitary and phytosanitary measures, public contracting, service trade (including financial and telecommunication services), electronic trade, and a mechanism for the resolution of commercial controversies. The foregoing represents important progress in relation to the experience and style of the negotiations for both countries while becoming a model for future agreements.

On the other hand, and based on the calculations made, it is noted that Colombia and Israel do not compete in terms of their exports because they export different goods. Concerning our country, it evidences a comparative advantage with respect to primary commodities and Israel with products that have more technological sophistication. Besides the foregoing, and despite the minimum bilateral trade, there is commercial potential since each one of the countries has the products the other wants to import. However (and as a topic for future studies) we must bear in mind that in Israel there is a high degree of protection of the agricultural sector, particularly to dairy products where, besides ad valorem tariffs, several contingent tariffs are applied.

Other findings are related to the concentration and similarities of the commercial goods in both economies. Concerning the concentration, except for oil, the concentration of products exported in Colombia is moderate; this opens the possibility of boosting trade. Regarding the similarity, it is low and with a decreasing trend: it means a very low competition risk in terms of the entry of tax exempt products, which may probably be protected with long-term tax exemption schedules or excluded from the agreement.

From the simulation of the model and analyzing diversions and creations in the trade of both economies, it is noted that the United States, China and the United Kingdom suffer the effects of trade diversion at a greater scale and that Israel generates more trade with Colombia.

From the point of view of the economic gains or losses, the agreement represents, even for a small amount, a loss for the producers and for the State, a profit for consumers in general, and a small welfare-related profit.

As a general conclusion, it has been identified that the agreement brings minimum benefits in terms of the trade of goods for both countries; however, Israel seems to benefit a little more than Colombia from the agreement.

Finally, some positive facts are perceived, as derived from the agreement, which may be studied in subsequent research. In the first place, the agreement represents the entry into the Middle East in terms of economic integration since it would be the first agreement Colombian signs with that region. In the second place, it can be stated that, even though there are no outstanding benefits from the results of this exploratory study for our country, the effect on certain sectors or specific companies may represent enriching commercial opportunities at the microeconomic level. A third element refers to the fact that the FTA, from a political perspective, may strengthen friendship and cooperation ties (as the text of the agreement reads) between both economies, thus creating an ally in terms of security and cooperation. A fourth element is represented by the possibility of technology transference related to research and development which could derive form the signing of the text.

\section{References}

Abdel J., T. (1971). A review article: The relevance of traditional integration theory to less developed countries.Journal of Common Market Studies, 9(3), 254-267. 
Andic, F., Andic, S., \& Dosser, D. (1971). A Theory of Economic Integration for Developing Countries. Londron: George Allen and Undwin Ltd.

Axline, W. A. (1977). Underdevelopment, dependence and integration: The politics of regionalism in the third world. Industrial Organization, 31(1), 83-105.

Balassa, B. (1961). The Theory of Economic Integration. Homewood, Illinois: Richard D: Irwin.

Balassa, B. (1965). Trade liberalisation and revealed comparative advantage. The Manchester School of Economic and Social Studies, 33(2), 99-123. https://doi.org/10.1111/j.1467-9957.1965.tb00050.x

Beris, J. (2008, 5 de julio). ¿Cuánto ayudó Israel a Colombia?. BBC News. URL: http://news.bbc.co.uk/hi/spanish/ latin_america/newsid_7491000/7491079.stm

Bhagwati, J. (1971). Trade-diverting customs unions and welfare-improvement: A clarification. The Economic Journal, 81(323), 580-587.

Bhagwati, J. (1992). Regionalism versus Multilateralism. The World Economy, 15(5), 535-556. http://dx.doi.org/10. $1111 / j .1467-9701.1992 . t b 00536 . x$

Bhambri, R. S. (1962). Customs Unions and underdeveloped countries. Economia Internazionale, 15(2), 15-17.

Boyer, I., \& Schuschny, A. (2010). Quantitative assessment of a free trade agreement between MERCOSUR and the European Union. Estudios Estadisticos y Prospectivos, 69 CEPAL. Santiago, Chile. URL: http://www.cepal.org /deype/publicaciones/xml/1/41551/lcl3158i.pdf

Chique, V., Rosales, R., \& Samacá, H. (2006.) Efectos de la liberalización comercial: un análisis de equilibrio parcial para el sector de arroz en Colombia. Documento CEDE No. 2006-37. Universidad de Los Andes. URL: https:/ /economia.uniandes.edu.co/files/jortegon@fundacionuniandes.edu.co/d2006-37.pdf

Chou, Y.-M. (1967). Economic Integration in less developed countries: The case of small countries. Journal of Development Studies, 3(4), 352-373.

Contreras, T., Mendieta, I., \& Huerta, R. (2012). Equilibrio parcial y general: dos problemas inquietantes. Ensayos de Economia, 41, 89-107. URL: http://www.bdigital.unal.edu.co/35518/1/35872-144072-1-PB.pdf

Cooper, C., \& Massell, B. (1965). A new look at customs union theory. The Economic Journal, 75(300), 742-747.

Corden, W. (1972). Economies of scale and customs union theory. Journal of Political Economy, 80, 456-475.

Danna-Buitrago, J. P. (2018). La alianza del pacífico+4 y la especialización regional de Colombia: Una aproximación desde las ventajas comparativas. Cuadernos de Administración, 30(55), 163-192. https://doi.org/10.11144/Jav eriana.cao30-55.aperc

Davis, L., Hanslow, K., \& Saunders, C. (2009). Estimating the impact of an Australia-Indonesia trade and investment agreement.URL: http://dfat.gov.au/trade/agreements/iacepa/Documents/aus-indon_fta_cie.pdf

Demas, W. G. (1965). The economics of development in small countries with special reference to the Caribbean. Montreal: McGill University Press.

Domingues, E., Haddad, E., \& Hewings, G. (2008). Sensitivity analysis in applied general equilibrium models: An empirical assessment for MERCOSUR free trade areas agreements. The Quarterly Review of Economics and Finance, 48(2), 287-306. doi: http://dx.doi.org/10.1016/j.qref.2006.12.018

Durán, J., \& Álvarez, M. (2008). Indicadores de comercio exterior y politica comercial: mediciones de posición y dinamismo comercial. Colección documentos de proyectos. Santiago de Chile: CEPAL/Naciones Unidas.

Esguerra, M., Iregui, A., \& Ramírez, M. (2004). Trade between Colombia and East Asia: An analysis using a CGE model. Ensayos sobre Política Económica, 45, 116-171. URL: http://www.banrep.gov.co/sites/default/files/pu blicaciones/archivos/espe_045-4.pdf

Francois, J., \& Reinert, K. (1997). Applied methods for trade policy analysis: A handbook. Cambridge: Cambridge University Press.

Freire, M., Alonso, M., González-Blanch, M., \& Blanco, F. (2013). Introducción a la macroeconomia: teoría y práctica. Madrid, España: ESIC Editorial.

Garay, L. J., Barberi, F., \& Cardona, I. (2010). Impactos del TLC con Estados Unidos sobre la economía campesina en Colombia. Bogotá: ILSA. 
Gómez, D., Pereira, C., \& Gaitán, L. (2013). Impacto de un TLC en el comercio entre Colombia y Turquía. Cuadernos de Administración, 26(46), 159-199. URL: http://revistas.javeriana.edu.co/index.php/cuadernos_admon/arti cle/view/5644/4602

Gracia, O., \& Zuleta, H. (2009). Tratado de libre comercio entre Colombia y Estados Unidos: ¿qué impacto puede tener en Colombia? Coyuntura Económica, 39(1), 99-148.

Guei, K., Mugano, G., \& Le Roux, P. (2017). Revenue, welfare and trade effects of European Union Free Trade Agreement on South Africa. South African Journal of Economic and Management Sciences, 20(1), 1-11.

Hernández, G. (2014). Una revisión de los efectos del Tratado de Libre Comercio entre Colombia y Estados Unidos. Lecturas de Economia, 80, 49-77. URL: http://www.scielo.org.co/pdf/le/n80/n80a2.pdf

Hernández, R. A. (2007). ¿Se erosiona la competitividad de Centroamérica y la República Dominicana con el fin del Acuerdo sobre los textiles y el vestido? Revista de la Cepal, 93, 109-127. URL: http://www.cepal.org/publicac iones/xml/8/31958/hernandez.pdf

Hoen, A., \& Oosterhaven, J. (2006). On the measurement of comparative advantage. The Annals of Regional Science, 40(3), 677-691. https://doi.org/10.1007/s00168-006-0076-4

Hosny, A. S. (2013). Theories of economic integration: A survey of the economic and political literature. International Journal of Economy, Management and Social Sciences, 2(5), 133-155.

Inotai, A. (1991). Regional integration among developing countries, revisited. Policy, Research and external affairs working paper. No 643. Washington, D.C: World Bank.

Israel Ministry of Foreign Affairs (IMFA). (2015, 3 de marzo). Israel-Panama free trade negotiations begin. URL: http://mfa.gov.il/MFA/InnovativeIsrael/Economy/Pages/Second-round-of-negotiations-on-Israel-Pan ama-free-trade-agreement-3-March-2015.aspx

Israel Ministry of Foreign Affairs (IMFA). (2015, 30 de marzo). Israel-China task force to be launched. URL: http://m fa.gov.il/MFA/InnovativeIsrael/Economy/Pages/israel-china-task-force-to-be-launched-30-march-2015.aspx

Jachia, L., \& Teljeur, E. (1999). Free Trade between South Africa and the European Union. United Nations Conference on Trade and Development (UNCTAD). Discussion Papers 141.

Jean, S., Mulder, N., \& Ramos, M. (2014). A general equilibrium, ex-post evaluation of the EU - Chile Free Trade Agreement. Economic Modelling, 41, 33-45. http://dx.doi.org/10.1016/j.econmod.2014.04.025.

Johnson, H. (1958). International Trade and Economic Growth. London: Allen \& Unwin.

Kitwiwattanachai, A., Doug, N., \& Reed, G. (2010). Quantitative impacts of alternative East Asia Free Trade Areas: A Computable General Equilibrium (CGE) assessment. Journal of Policy Modeling, 32(2), 286-301. http://dx .doi.org/10.1016/j.jpolmod.2009.07.002

Krishna, P. (1998). Regionalism and multilateralism. A political economy approach. The Quarterly Journal of Economics, 113(1), 227-251.

Laird, S., \& Yeats, A. (1986). The UNCTAD trade policy simulation model. United Nations Conference on Trade and Development, 19. Available on line: http://wits.worldbank.org/data/public/SMARTMethodology.pdf

Laird, S., \& Yeats, A. (1990). The magnitude of two sources of bias in standard partial equilibrium trade simulation models. Journal of Policy Modelling, 14(1), 121-130. http://dx.doi.org/10.1016/0161-8938(92)90027-A

Lawrence, R. (1997). Regional partners in global markets: Limits and possibilities of the Euro-Med Agreements. In A. Galal \& B. Hoekman (eds.), Preferential trading arrangements: The traditional and the new. CEPR and ECES.

Linder, S., \& Wionczek, M. (Eds.). (1966). Customs unions and economic development. In Latin American Economic Integration. New York: Praeger.

Maesso, M. (2011). La integración Económica. Revista ICE Tendencias y nuevos desarrollos de la teoría económica. Ministerio de Industria Turismo y Comercio, 858, 119-132.

Martin, C., \& Ramírez, J. (2004). El impacto económico de un acuerdo parcial de libre comercio entre Colombia y Estados Unidos. Borradores de Economía No. 326. Banco de la República. URL: http://banrep.gov.co/docum /ftp/borra326.pdf 
Mathur, S. (2014). Trade in Climate Smart Goods of Ecuador: Quantitative Analysis Using Trade Indices, SMART and gravity Analysis. Journal of International Economics, 5(1), 31-64.

McCalman, P. (2018). International trade, income distribution and welfare. Journal of International Economics, 110, $1-15$.

McKitrick, R. R. (1998). The econometric critique of computable general equilibrium modeling: The role of functional forms. Economic Modelling, 15, 543-573.

Michaely, M. (1996). Trade Preferential Agreements in Latin America: An Ex Ante Assessment. World Bank Policy Research Working Paper No. 1583. Washington D.C.: The World Bank.

Ministerio de Comercio Industria y Turismo (MinCIT). (2011, 15 de marzo). Colombia inicia negociaciones para un Tratado de Libre Comercio con Turquia. URL: http://www.mincit.gov.co/publicaciones.php?id=17983

Ministerio de Comercio Industria y Turismo (MinCIT). (2014, 20 de mayo). Terminó en Tokio V Ronda de Negociaciones para Acuerdo con Japón. URL: http://www.mincit.gov.co/publicaciones.php?id=9768

Mugano, G., Le Roux, P., \& Brookes, M. (2013). The impact of most favoured nation tariff rate on Zimbabwe. International Journal of Physical and Social Sciences, 3(7), 231-245.

Naito, T. (2017). Growth and welfare effects of unilateral trade liberalization with heterogeneous firms and asymmetric countries. Journal of International Economics, 109, 167-173.

Organización Mundial del Comercio (OMC). (2012). Examen de las Políticas Comerciales - Informe de la Secretaría: Israel. Documento No. WT/TPR/S/272

Otheino, L., \& Shinyekwa, I. (2011). Trade, revenue and welfare effects of the East African Community Customs Union Principle of Asymmetry on Uganda: An Application of WITS-SMART Simulation Model. EPRC Research Series No. 79. Kampala, Ugandan: Economic Policy Research Center. URL: http://www.eprc.or.ug/ pdf_files/series79.pdf

Padilla, N. F. (2009, 8 de agosto). La conexión israelí. El Espectador. URL: http://www.elespectador.com/impreso/a rticuloimpreso155158-conexion-israeli

Panagariya, A. (1998). The regionalism debate. An overview. University of Maryland.

Pereira, C., Gómez, D., \& Herrera, L. (2012). The Colombia - Canada Free Trade Area: a Partial Equilibrium Simulation. Semestre Económico, 15(31), 15-42. URL: http://www.scielo.org.co/pdf/seec/v15n31/v15n31a2.p df

Plummer, M., Cheong, D., \& Hamanaka, S. (2010). Methodology for Impact Assessment of Free Trade Agreements. Manila, Philippines: Asian Development Bank.

Proudman, J., \& Redding, S. (1998). Openness and growth. London, United Kingdom: The Bank of England.

Ramírez, J. L. (1989). La proclamación del Estado Palestino y sus implicaciones en las relaciones internacionales de Colombia. Colombia Internacional, 5, 3-10.

Redding, S. (2016). Goods trade, factor mobility and welfare, Journal of International Economics. Journal of International Economics, 101, 148-167.

Sabaruddin, S. (2016). Dampak Liberalisasi Perdagangan RI-China Terhadap Perubahan Perdagangan dan Kesejahteraan Masyarakat Indonesia: Ssebuah Pendekatan Ekuilibrium Parsial (SMART Model) dan Pemanfaatan Sistem Neraca Sosial Ekonomi 2008. Jurnal Ekonomi dan Bisnis, 17(3), 33-54.

Sakamoto, J. (1969). Industrial development and integration of underdeveloped countries. Journal of Common Market Studies, 7(4), 283-304.

Shamah, D. (2015, 27 de marzo). Latin America rolls out red carpet for Israeli trade. Times of Israel. URL: http://ww w.timesofisrael.com/latin-america-rolls-out-red-carpet-for-israeli-trade/

Spraos, J. (1964). The condition for a trade-creating customs union. The Economic Journal, 74(293), 101-108.

Stibora, J., \& de Vaal, A. (2015). Does Preferential Trade Benefit Poor Countries? A General Equilibrium Assessment with Nonhomothetic Preferences. Review of International Economics, 23(2), 239-270. http://dx.doi.org/10.11 $11 /$ roie. 12170 
Sulthon, S. S. (2014). The impact of Indonesia-China Trade liberalisation on the welfare of indonesian society and on export competitiveness. Bulletin of Indonesian Economic Studies, Taylor \& Francis Journals, 50(2), 292-293.

Święcki, T. (2017). Intersectoral distortions and the welfare gains from trade. Journal of International Economics, 104, 138-156.

Villaverde, J., \& Maza, A. (2014). The Impact of the Transatlantic Trade and Investment Partnership (TTIP) on the Spanish Regions. Swedish Institute for European Policy Studies, 2015(12), 1-16. URL: http://www.sieps.se/site s/default/files/Sieps\%202015_12epa\%20eng\%20A4.pdf

Wonnacott R. J., \& Wonacott, P. (1967). Free Trade between the United States and Canada: The Potential Economic Effects. Cambridge, Mass: Harvard University Press.

Yeats, A. J. (1985). On the appropriate interpretation of the revealed comparative advantage index: implications of a methodology based on industry sector analysis. Review of World Economics, 121(1), 61-73.

Yu, R., Cai, J., \& Leung, P. (2009). The normalized revealed comparative advantage index. The Annals of Regional Science, 43(1), 267-282. http://dx.doi.org/10.1007/s00168-008-0213-3

\section{Annex}

\section{Description of products with comparative advantages for both Colombia and Israel}

Table A.1 shows the products in which Colombia has advantages over Israel, and table A.2 shows the products in which Israel has advantages over Colombia. The tables are limited to the main fifteen products.

TABLE A.1

Products (main 15) with a comparative advantage in Colombia vis-à-vis Israel

\begin{tabular}{|c|l|c|c|c|c|}
\hline HS-6 & \multicolumn{1}{|c|}{ Product description } & $\begin{array}{c}\text { NRCAI } \\
2012\end{array}$ & $\begin{array}{c}\text { NRCAI } \\
2013\end{array}$ & $\begin{array}{c}\text { NRCAI } \\
\mathbf{2 0 1 4}\end{array}$ & $\begin{array}{c}\text { Average } \\
\text { NRCAI }\end{array}$ \\
\hline 930599 & Parts and accessories for weapons and the like of heading 9303 or 9304 & 0,98 & 0,98 & 0,98 & 0,98 \\
\hline 440290 & Wood charcoal, incl. shell or nut charcoal, whether or not agglomerated & 0,95 & 0,96 & 0,93 & 0,95 \\
\hline 841191 & Parts of turbojets or turbopropellers & 0,8 & 0,86 & 0,91 & 0,86 \\
\hline 901420 & Instruments and appliances for aeronautical or space navigation & 0,59 & 0,82 & 0,97 & 0,79 \\
\hline 270112 & Bituminous coal, whether or not pulverized, non-agglomerated & 0,77 & 0,79 & 0,78 & 0,78 \\
\hline 440929 & $\begin{array}{l}\text { Wood, incl. strips and friezes for parquet flooring, not assembled, continuously } \\
\text { shaped }\end{array}$ & 0,48 & 0,9 & 0,87 & 0,75 \\
\hline 844399 & Parts and accessories of printers, copying machines and facsimile machines & 0,57 & 0,75 & 0,75 & 0,69 \\
\hline 854231 & Electronic integrated circuits as processors and controllers, whether or not combined & 0,74 & 0,32 & 0,21 & 0,42 \\
\hline 392190 & $\begin{array}{l}\text { Plates, sheets, film, foil and strip, of plastics, reinforced, laminated, supported or } \\
\text { similarly }\end{array}$ & 0,26 & 0,48 & 0,34 & 0,36 \\
\hline 820590 & $\begin{array}{l}\text { Anvils; portable forges; hand- or pedal-operated grinding wheels with frameworks; } \\
\text { sets of articles }\end{array}$ & 0,98 & -1 & 0,94 & 0,31 \\
\hline 902129 & Dental fittings (excluding artificial teeth) & -1 & 0,84 & 0,92 & 0,25 \\
\hline 440729 & $\begin{array}{l}\text { Tropical wood specified in Subheading Note } 1 \text { to this chapter, sawn or chipped } \\
\text { lengthwise, sliced }\end{array}$ & 0,95 & 0,78 & -1 & 0,25 \\
\hline 852910 & Aerials and aerial reflectors of all kinds; parts suitable for use therewith & -1 & 0,8 & 0,93 & 0,24 \\
\hline 481820 & $\begin{array}{l}\text { Handkerchiefs, cleansing or facial tissues and towels, of paper pulp, paper, cellulose } \\
\text { wadding }\end{array}$ & 0,59 & 0,7 & 0,56 & 0,24 \\
\hline 902690 & $\begin{array}{l}\text { Parts and accessories for instruments and apparatus for measuring or checking the } \\
\text { flow or level }\end{array}$ & -1 & 0,68 & 0,96 & 0,21 \\
\hline
\end{tabular}


TABLE A.2

Products (main 15) with a comparative advantage in Israel vis-à-vis Colombia

\begin{tabular}{|c|l|c|c|c|c|}
\hline HS-6 & \multicolumn{1}{|c|}{ Product description } & $\begin{array}{c}\text { NRCAI } \\
\mathbf{2 0 1 2}\end{array}$ & $\begin{array}{c}\text { NRCAI } \\
\mathbf{2 0 1 3}\end{array}$ & $\begin{array}{c}\text { NRCAI } \\
\mathbf{2 0 1 4}\end{array}$ & $\begin{array}{c}\text { Average } \\
\text { NRCAI }\end{array}$ \\
\hline 901820 & $\begin{array}{l}\text { Uitraviolet or infra-red ray apparatus used in medical, surgical, dental or veterinary } \\
\text { sciences }\end{array}$ & 1 & 1 & 1 & 1 \\
\hline 851770 & $\begin{array}{l}\text { Parts of telephone sets, telephones for cellular networks or for other wireless } \\
\text { networks }\end{array}$ & 1 & 1 & 1 & 1 \\
\hline 841191 & Parts of turbojets or turbopropellers & 1 & 1 & 1 & 1 \\
\hline 60210 & Unrooted cuttings and slips & 1 & 1 & 0,98 & 1 \\
\hline 903180 & Instruments, appliances and machines for measuring or checking & 1 & 1 & 1 & 1 \\
\hline 847190 & $\begin{array}{l}\text { Magnetic or optical readers, machines for transcribing data onto data media in coded } \\
\text { form }\end{array}$ & 1 & 1 & 1 & 1 \\
\hline 902610 & Instruments and apparatus for measuring or checking the flow or level of liquids & 0,98 & 0,98 & 0,99 & 0,99 \\
\hline 842481 & Agricultural or horticultural mechanical appliances, whether or not hand-operated & 0,99 & 0,99 & 1 & 0,99 \\
\hline 130219 & Vegetable saps and extracts (excluding liquorice, hops and opium) & 1 & 1 & 0,93 & 0,99 \\
\hline 902290 & $\begin{array}{l}\text { X-ray generators other than X-ray tubes, high tension generators, control panels and } \\
\text { desks }\end{array}$ & 1 & 1 & 0,98 & 0,99 \\
\hline 848110 & Pressure-reducing valves & 1 & 1 & 0,98 & 0,99 \\
\hline 830110 & Padlocks of base metal & 1 & 1 & 0,99 & 0,99 \\
\hline 903120 & Test benches for motors, generators, pumps, etc. & 1 & 1 & 0,99 & 0,99 \\
\hline 853710 & $\begin{array}{l}\text { Boards, cabinets and similar combinations of apparatus for electric control or } \\
\text { distribution }\end{array}$ & 0,98 & 0,97 & 0,96 & 0,98 \\
\hline 842490 & $\begin{array}{l}\text { Parts of fire extinguishers, spray guns and similar appliances, steam or sand blasting } \\
\text { machines }\end{array}$ & 0,25 & 0,25 & 0,25 & 0,25 \\
\hline
\end{tabular}

Source: author compilation based on data from International Trade Center.

\section{Notes}

* Research paper.

1 Remember that there are different types and stages of integration: according to Balassa (1961), the first one is the Free Trade Area (FTA), Customs Union, Common Market, and the Economic Union. The Free Trade Areas are a special case of a wider category called Preferential Trade Agreements (PTAs) (Panagariya, 1998).

2 There is a government report, (without a specific authorship and without being an academic article "Israel - Colombia Joint Study on the Feasibility of an FTA" of 2011), signed by the Colombian Deputy Minister of Commerce, Industry and Tourism and by the Deputy General of Foreign Trade of the Ministry of Industry, Trade and Labor of Israel. The document presents some conclusions very briefly. It recommends carrying out the FTA between the two countries, using among other tests, the SMART model for commercial and tariff data of 2009. Hence, an FTA between Colombia and Israel would have a positive impact on their economic and commercial relations, for both parties, showing among their results that total exports increase $15 \%$ in real terms. It estimates a growth of Colombian exports of $2 \%$ because oil and coffee have a zero tariff to enter Israel.

3 In other words, a tariff increases the cost of imports and leads the price paid by the local consumers to be higher than the amount received by the foreign producers; this means that when the prices of imported goods become higher they become less competitive in the import country.

4 Traditional index only shows the presence (or not) of advantages, but not which product has more advantages.

5 The index takes values between $-1 / 4$ and $+1 / 4$. But as Yu et al. (2008, p. 273) explain, the results can be transformed into a range of -1 and +1 "which might facilitate the presentation and discussion of the results".

6 For a better understanding of the determination of variables in the model, using SMART, it is recommended to consult: https://wits.worldbank.org/wits/wits/witshelp-es/Content/SMART/SMART\%20Theoretical\%20Frame work1.htm https://www.unescap.org/sites/default/files/7.Session6-Analysis\%20in\%20SMART.pdf

$7 \quad$ Nevertheless, an annotation is relevant to the interpretation of this effect. If the export supply were not infinite (as the model assumes), then the reduction in prices as a result of tariff reduction will be less than expected because export prices will increase and the imports will not increase in the same proportion to tariff reduction. Therefore, the welfare effect needs to be interpreted as a combination of consumer surplus and producer surplus.

\section{Licencia Creative Commons CC BY 4.0}

Cited as: Venegas C., S. P., y De la Peña C., N. (2019). Estimation of the comercial effect of the ColombiaIsrael FTA. Previous partial aquilibrium analysis, 2004-2014. Cuadernos de Administración, 32(59) 